\title{
A tribute to Terry Strom
}

T erry Barton Strom, a giant in the field of transplantation immunology, died in Boston on December 20th, surrounded by friends and family, at the age of 76 . He will be remembered by all whose path he crossed for his intellect and persona.

Terry grew up on the South Side of Chicago (more on that later) and went on to start his undergraduate studies at the University of Illinois. He entered medical school at the University of Illinois after his junior year, and - having never satisfied the foreign language requirement of the University - could not be awarded a bachelor's degree. Thus, he was one of the rare physicians and academicians to have never graduated from college (although Harvard later awarded him a degree). This certainly did not hold him back. Following medical school, Terry was an intern in medicine at the University of Illinois and was then recruited to be a senior resident in medicine at the Beth Israel Hospital, after which he was renal fellow at the Peter Bent Brigham Hospital. On the completion of his clinical training, he worked in the lab of gentleman-scholar Charles (Bernie) Carpenter, entering and helping define the then nascent field of transplantation immunology. He was among the first and most distinguished of a long line of scientists to emerge from the Carpenter laboratory, the authors of this tribute include.

Following his formal laboratory training, Terry's initial faculty appointment was at the Pent Brigham Hospital, and he later moved across the street to the Beth Israel Deaconess Hospital, where he stayed for the rest of his distinguished career. He established the Department of Immunology, rose through the ranks to become a Professor of Medicine and Surgery at Harvard Medical School, trained and mentored many fine scientists, and made numerous discoveries that have improved the lives of transplant recipients as well as patients with autoimmune diseases. A prolific author of almost 500 original articles, Terry's seminal studies were models of clarity. For example, one of his early publications in the Proceedings of the National Academy of Sciences was the first description of cholinergic agents augmenting lymphocyte-mediated cytotoxicity (LMC), an effector mechanism central to the rejection of histoincompatible grafts (1). This original observation was rapidly amplified within a year by a publication in Science regarding the importance of microtubule integrity in LMC (2) and a publication in the Journal of Experimental Medicine regarding the counter-regulatory role of cyclic nucleotides on LMC (3). Yet

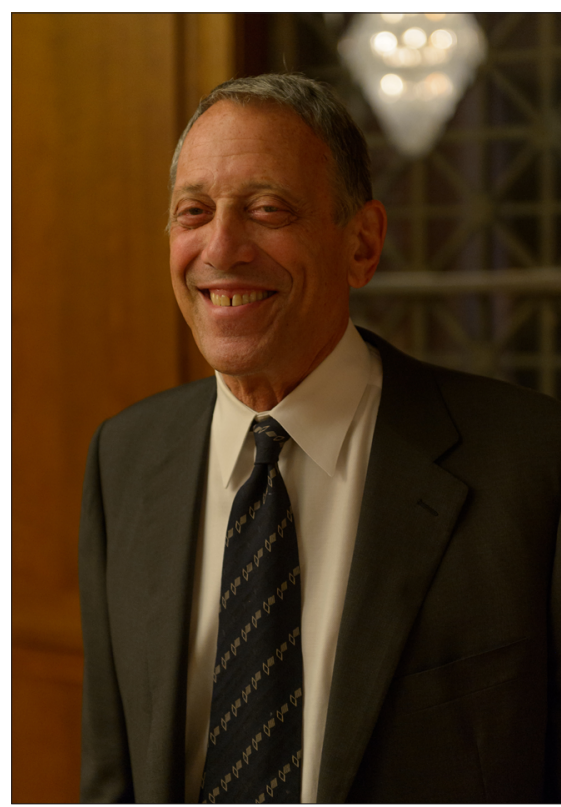

another novel observation was the finding that insulin augmented LMC (published in Science) (4) followed by the demonstration of insulin receptors on alloimmune $\mathrm{T}$ cells (reported in the JCI) (5) that functioned as markers of activated T cells and B cells (reported in Nature) (6). These early studies foreshadow our current interest in $\mathrm{T}$ cell metabolism and identification of antigen-reactive cells via activation markers.

Terry's preclinical investigations helped advance IL-2 receptor $\alpha(C D 25)$ as a suitable target to prevent rejection in organ graft recipients, an idea that has been successfully translated to the clinic. Terry's incisive studies have not only enabled clinical application of monoclonal antibodies, but have also improved our understanding of several immunosuppressive drugs currently used in the transplantation arena, including cyclosporine, glucocorticoids, and mTOR inhibitors.

Ever alert to promising inventions, Terry adopted the PCR assay to pioneer the characterization of intragraft gene expression patterns in preclinical transplantation models and, subsequently, in rejecting human allografts. In the spirit of "A man should look for what is and not for what he thinks should be," Terry and his talented team unhesitatingly reported that acute rejection, previously considered a consequence primarily of graft-destructive immunity, is unexpectedly associated with the development of suppressor cells. Finally, a logical extension of this technology led to the exploration of peripheral blood gene expression patterns as biomarkers of allograft status.

Thus, Terry's lab had a transformative impact in our understanding of transplant rejection and our goal of achieving transplant tolerance.

In recognition of his seminal contributions, Terry was honored by numerous awards, including election to the ASCI (almost 40 years ago), the Homer Smith Award of the American Society of Nephrology, the Starzl Prize in Surgery and Immunology, and the Established Investigator Award and Distinguished Achievement award, both from the American Society of Transplantation (AST). He is a past president of the AST and the founding president of Clinical Immunology Society. In recognition of his mentorship, Terry was awarded the AST Mentoring Award. Indeed, Terry is the recipient of every honor the AST can bestow on a transplant physician scientist. We had the privilege of collaborating with Terry in some of these studies and, like others who worked with him, admired his intellectual creativity and envied his ability to think outside the box. And not surprisingly, he was beloved by his patients.

The accomplishments above are truly impressive, but what those fortunate enough to know Terry will remember even more is his outsized personality. Terry was 
a character - there is no better word. He exuded boyish charm. With his full head of hair, gap-toothed smile, and large (6'4") stature, he was a legend (see accompanying image). Befittingly, his son called him "Big T" and his brother called him "Zeus." Growing up in a rough-and-tumble Polish neighborhood on Chicago's South Side, Terry was the big Jewish kid - a target but he learned to "give as good as he got." He was also, by all accounts, a bad-ass kid. Those who had the privilege of knowing Terry as an adult will probably not be surprised that he was expelled from Hebrew school for throwing eggs at the rabbi. Or that, while serving in the Air Force (and it is truly hard to imagine Terry in the military), he did volunteer work for the Black Panthers. However, they might be surprised to learn that he had a life-time ban at the famed Drake Hotel on Michigan Avenue for serially crashing weddings, culminating in a food fight involving the wedding cake. At least that's the legend, but if you knew Terry, you knew that it was eminently believable. And no one who knew Terry would be surprised that he was tremendously proud of these stories. $\mathrm{He}$ reveled in rising from humble beginnings to the peak of a lofty profession. And he loved being a rebel.

In addition to his intellectual talents, Terry was a gifted athlete. A rising high school football player, he and Dick Butkus were featured together in the local news. But two life-threatening subdural hematomas put an end to his athletic career. After recovering from surgery and emerging from a coma, his family and friends found him a changed man, no longer the prankster of earlier days. His lifelong friend Jon Borus refers to it as a "therapeutic/traumatic injury," one that enabled him to focus his talents - and we are all better off for it.

While no longer a competitive athlete, Terry remained fiercely competitive. His children recall races in the park and hardfought basketball games in the driveway that were always fun but were also training for life, where someone was always bigger and better, and you had better get used to it. In the halcyon days of postgraduate training when every minute of fellowship did not have be accounted for, one of the authors (identity intentionally concealed!) of this piece recalls very fondly spending several afternoons in Terry's club playing what started as a friendly game of tennis and ending in a highly competitive brawl. A devoted fan, Terry thrilled in the success of Boston teams, but especially the Celtics. Among Terry's many other hobbies, his love of wine and wine-making particularly stand out. He was especially proud that a dessert wine he had made one year with purchased grapes found its way onto the wine list of one of Boston's finest restaurants. His friends also remember an exceedingly generous man - one who would take you into his home in hard times and be with you when you needed him.

An event that exemplifies Terry's utmost humanism is one personally experienced by one of the authors of this tribute (M. Suthanthiran).

"On the first day of my transplant fellowship, I had to call Terry, my transplant attending, to seek his permission to return to Detroit Children's Hospital to attend to my 9-year-old nephew, who had just been readmitted for a postoperative complication following total correction of Tetralogy of Fallot," Suthanthiran said. "I was deeply concerned about making this request on my very first day of fellowship. Despite the unanticipated burden imposed on him by the sudden absence of the renal fellow on a very busy transplant service, Terry, without any hesitation whatsoever, said in the most caring voice, 'Please, go and come back only when you feel comfortable."'

Terry's death was due to complications of an allogeneic stem cell transplant he received as part of his treatment for myelofibrosis (itself occurring as a complication of an earlier, and curative, autologous stem cell transplant for myeloma). He could have opted for maintenance transfusions but, instead, chose a riskier but potentially curative treatment. It reflected his tremendous optimism and joie de vivre, which were palpable to all he knew. One only had to be lucky enough to enjoy a meal or drink with friends at Terry and his wife Margot's home in Brookline (where they lived together for almost 50 years) to see his spirit in action.

In many religions and belief systems, there is a variation of the aphorism that one must leave the world better than one finds it. Terry Strom - our brilliant mentor and dear friend - has most certainly not only enriched the field of immunobiology and transplantation, but also stimulated each of us to be better individuals.

Terry Strom was blessed with a wonderful family. The authors thank them - in particular his wife, Margot, and children, Adam and Rachel, - for sharing their memories of Terry. We join them in mourning his passing; we are all poorer for it.

\section{Laurence A. Turka and Manikkam Suthanthiran}

Departments of Surgery and Medicine, Massachusetts General Hospital, and Rheos Medicines, Boston, Massachusetts, USA. Departments of Medicine and Transplantation Medicine, New York Presbyterian, Weill Cornell Medicine, New York, New York, USA.

1. Strom TB, Deisseroth A, Morganroth J, Carpenter CB, Merrill JP. Alteration of the cytotoxic action of sensitized lymphocytes by cholinergic agents and activators of adenylate cyclase. Proc Natl Acad Sci U S A. 1972;69(10):2995-2999.

2. Strom TB, Garovoy MR, Carpenter DB, Merrill JP. Microtubule function in immune and nonimmune lymphocyte-mediated cytotoxicity. Science. 1973;181(4095):171-173.

3. Strom TB, Carpenter CB, Garovoy MR, Austen KF, Merrill JP, Kaliner M. The modulating influence of cyclic nucleotides upon lymphocyte-mediated cytotoxicity. J Exp Med. 1973;138(2):381-393.

4. Strom TB, Bear RA, Carpenter CB. Insulininduced augmentation of lymphocyte-mediated cytotoxicity. Science. 1975;187(4182):1206-1208.

5. Helderman JH, Strom TB. Emergence of insulin receptors upon alloimmune $\mathrm{T}$ cells in the rat. J Clin Invest. 1977;59(2):338-344.

6. Helderman JH, Strom TB. Specific insulin binding site on $\mathrm{T}$ and $\mathrm{B}$ lymphocytes as a marker of cell activation. Nature. 1978;274(5666):62-63. 